\title{
Trypanosoma cruzi Cysteine Proteases, Acting at the Interface Between the Vascular and Immune Systems, Influence Pathogenic Outcome in Experimental Chagas Disease
}

\author{
Julio Scharfstein*
}

\author{
Instituto de Biofísica Carlos Chagas Filho, Universidade Federal do Rio de Janeiro, CCS-Cidade Universitária, Rio de \\ Janeiro, Brasil
}

\begin{abstract}
Trypanosoma cruzi proteases were object of intensive structural and functional characterization in the past decades. The celebration of the Chagas disease centenarian makes it opportune to review the foundations of molecular research on cruzipain, a major lysosomal cysteine protease. Acting as a virulence factor, cruzipain promotes intracellular parasitism. In addition, tissue culture trypomastigotes (TCTs) exploit the enzymatic versatility of cruzipain to liberate kinin peptides from kininogen molecules associated to heparan sulfate proteoglycans. Acting as paracrine agonists, the released kinins (eg, lysyl-bradykinin) potentiate parasite invasion of cardiovascular cells through the signaling of heterotrimeric G-protein coupled bradykinin receptors (BKRs). Generation of kinins also stimulates immunity, implying that cruzipain activity brings mutual benefits for the host-parasite relationship. Analysis of the dynamics of inflammation revealed that TCTs induce secretion of KC/MIP-2 by macrophages via signaling of Toll-like 2 receptors (TLR2). Acting on proximal microvascular beds, CXC chemokines evoke plasma extravasations by activating endothelium/neutrophils via CXCR2. Diffusion of plasma proteins (including kininogens) through extracellular matrices allow for cruzipain-dependent generation of vasoactive kinins, which then intensify interstitial edema through the activation of endothelial $\mathrm{BK}_{2} \mathrm{R}$. Extent of edematogenic inflammation is counter-regulated by angiotensin converting enzyme (ACE), a kinin-degrading metallopeptidase. Acting at the interface between the vascular and the immune systems, kinins activate $\mathrm{BK}_{2} \mathrm{R}$ of dendritic cells, which then migrate to $\mathrm{T}$ - cell rich areas of secondary lymphoid tissues, where they induce immunoprotective type- 1 effector $\mathrm{T}$ cells. Insight into the mechanisms regulating proteolysis in extravascular sites of infection may help to identify susceptibility markers of chronic heart disease.
\end{abstract}

Keywords: Chagas disease, chagasin, cruzipain, kinins, Toll-like 2 receptors, Trypanosoma cruzi.

\section{INTRODUCTION}

After decades of research, a large body of studies in humans [1-4] and animal models [5] indicate that lowgrade/persistent tissue parasitism is the primary mechanism underlying chronic chagasic myocardiopathy (CCM). Albeit not excluding a secondary role for autoimmunity [6,7], this concept provides a solid framework to investigate the pathogenic roles of parasite antigens and pro-inflammatory molecules in CCM. During the course of chronic infection, there is sparse intracellular parasitism in the myocardium; hence the interstitial spaces are only sporadically exposed to intracellular T. cruzi released from disrupted host cells. Endowed with a moving flagellum, the freshly released trypomastigotes rapidly move away from the primary foci of infection, seeking for a safer (i.e., non-inflamed) environment to efficiently propagate the infection. In addition, depending on the interplay of host/parasite genetics, infected host cells may be prematurely killed, releasing variable numbers of amastigotes in the interstitial spaces. In contrast to the highly mobile trypomastigotes, the extracellular amastigotes (devoid of a moving flagellum) tend to cluster in the surroundings of the

*Address correspondence to this author at the Instituto de Biofísica Carlos Chagas Filho, Universidade Federal do Rio de Janeiro, CCS-Cidade Universitária, Rio de Janeiro, Brasil; Tel: +55-21-2209-6591; Fax: +55-21-22808193; E-mail: scharf@biof.ufrj.br primary infection foci, perhaps accounting for most, if not all, the sparse antigen deposits detected in heart specimens of CCM patients $[2,3,8]$. In the present article, I will discuss the hypothesis that infection-associated pathology may be aggravated as result of parasite-induced activation of proinflammatory proteolytic cascades.

\section{Infection-Associated Vasculopathy May Contribute to CCM}

Several decades ago, pathologists were intrigued by the findings that myocardial specimens from CCM patients often displayed diffused inflammatory infiltrates and evidence of extensive fibrosis in heart tissues despite the fact that pseudocysts were rarely found in such sections. As detection methods improved, researchers realized that a minor fraction of the intracellular parasites use multiple strategies [9-11] to subvert the selective pressure imparted by anti-parasite (type 1) effector $\mathrm{CD}^{+} \mathrm{T}$ cells [5]. In most patients, however, chronic infection does not lead to clinically active heart disease, implying that anti-parasite effector T cells may succeed at controlling intracellular parasite outgrowth in the myocardium without necessarily causing collateral damage. In approximately $30 \%$ of the patients, however, persistence of $T$. cruzi in the myocardium is associated with chronic immunopathology and fibrosis [12]. Studies in patients have linked severity of CCM to (i) increased myocardial infiltration by $\mathrm{TNF}-\alpha$-producing $\mathrm{CD} 8^{+} \mathrm{T}$ cells $[1,2,13]$ (ii) higher 
frequency of parasite-specific IFN- $\gamma$-producing $\mathrm{CD}^{+} \mathrm{T}$ cells in peripheral blood [14]. Analysis of IL-10 gene (promoter) polymorphism suggested that CCM may be a consequence of dysregulated $\mathrm{T}_{\mathrm{H}} 1$-dependent pathology, presumably aggravated in patients that produce lower levels of the regulatory IL-10 cytokine [15].

Proponents of the vascular theory have long argued that infection-associated microvascular lesions may build up over the years, inducing hypoxia and myocardial tissue injury. Accordingly, vasculopathy may converge with chronic immunopathology, thus intensifying the heart fibrosis that characterizes CCM [16-19]. Tanowitz and co-workers have extensively investigated the mechanism underlying chagasic vasculopathy in mice infected with $T$. cruzi [20,21]. Focusing on endothelin 1 (ET-1), a potent vasoconstrictor, these authors compared the outcome of chronic infection in wild type mice as compared to mice deficient in ET-1. Experiments conducted with ET-1 flox/flox; $\alpha-\mathrm{MHC}-\mathrm{Cre}(+)$ mice (in which the ET-1 gene was deleted from cardiac myocytes) and ET- ${ }^{1 \text { flox/flox }}$; Tie 2 Cre $(+)$ mice (in which the ET-1 gene was deleted from endothelial cells) showed that cardiac symptoms were only attenuated in the former group of ET-1 deficient animals [20]. Interestingly, inflammation scores were similar in all groups of infected mice, whereas chronic fibrosis was reduced in ET- $1^{\text {flox/flox }} ; \alpha-$ MHC-Cre $(+)$ mice. Furthermore, they noted a significant increase in the right ventricular internal diameter (RVID) of all infected mice, except for the ET-1 flox/flox $; \alpha$-MHC-Cre (+) mice strain. In addition, all infected mice showed increased left ventricular and diastolic diameter, reduced fractional shortening, and decreased relative wall thickness, while ET- 1 floxfllox $; \alpha$ MHC-Cre (+) mice displayed less severe alterations [20]. Pooling results from magnetic resonance imaging and echocardiography, these authors proposed that clinical outcome of CCM may be worsened as result of ET-1 upregulation by cardiac myocytes [20].

\section{Parasite Molecules Involved in Endothelium Activation}

In the early 80's, Libby and co-workers [22] reported that endothelial cells and cardiomyocytes underwent desialylation upon treatment with $T$. cruzi neuraminidase, an enzyme later characterized as a trans-sialidase (TS) [23,24]. More recently, Todeschini, Mendonça-Previato and coworkers re-examined the interaction of TS with the endothelium [25] using a catalytically inactive form of recombinant TS. Accordingly, TS binds to endothelial cell surface molecules containing $\alpha 2,3$-linked sialic acid endothelium via the TS lectin binding site. In a subsequent study, these authors found that these catalytically inactive TS recombinant molecules activate $\mathrm{NF}-\kappa \mathrm{B}$, upregulate expression of adhesion molecules, and block apoptosis induced by growth factor deprivation [26]. Although not explored in the above mentioned studies, TS antigens shed by TCTs [27] may play a role in the microangiopathy observed in $T$. cruzi-infected animals [28]. Endothelium injury by antibody-mediated cellular cytotoxicity (ADCC) may also occur as result of cellsurface deposition of anti-TS IgG antibodies present in chagasic serum [29]. Alternatively, cardiovascular cells decorated with TS antibodies might be killed by complement mediated lysis.
Focusing on endogenous lipids of $T$. cruzi, Ashton and co-workers recently demonstrated that thromboxane $\mathrm{A}(2)$ (TXA2) are the predominant eicosanoids lipids [30] produced by this pathogen. Levels of TXA 2 produced by amastigotes are significantly higher than those of trypomastigotes or epimastigotes. Notably, they also found that parasitederived TXA 2 accounts for $90 \%$ of the circulating levels of TXA2 present in infected mouse [30]. TXA2 signaling seems to contribute to host resistance because mice deficient in the thromboxane receptor bear a highly susceptible phenotype [30]. Studies with endothelial cells revealed, however, that intracellular T. cruzi growth is hampered in cells deficient on TXA2 receptors. Together, these results suggest that parasite-derived TXA2 may have dual roles in the maintenance of host/parasite balance [30]. Another research line [39] indicated that $T$. cruzi synthesizes a platelet-activating factor (PAF)-like lipid that enhances differentiation of epimastigotes into metacyclic trypomastigotes. It remains to be determined if PAF-like lipids expressed by $T$. cruzi may play a role in pathogenesis.

It is well-established that $T$. cruzi can be sensed by sentinel cells of the innate immune system [32-39] through germline encoded trans-membrane receptors of the TLR family. Although T. cruzi is empowered with 4 distinct TLR ligands [33-37], two of these consist of lipid structures [33,34]. Biochemical analyzes of mucin-linked glycosylphosphatidylinositol-anchors of TCTs (tGPI) identified the lipid acyl chain as the developmentally regulated microbial signature $[37,38]$ that elicits inflammation via TLR2 [32,33]. Studies in macrophages from TLR deficient mice indicated that TLR2/TLR6 [32,33,36], TLR4 [34] and TLR9 [36] are upstream regulators of the early proinflammatory cytokine response [32]. There is also evidence that TCTs activate NF$\mathrm{kB}$ and upregulate IL-1 $\beta$ production in cardiomyocytes via the TLR2 pathway [40]. Additional studies in mice showed that purified tGPI-mucin induced neutrophil accumulation in the mouse pleura via the TLR2/MCP-1 pathway [41]. As explained later on in this review, TCTs evoke interstitial edema via mechanisms involving cooperation between tGPI and parasite-derived cysteine proteases.

\section{Foundations of Molecular Research on Cruzipain: A Brief Retrospective}

Although there are excellent reviews on this subject [4245], the centenarian of Chagas disease makes it opportune to describe how molecular research on cruzipain has evolved. In the late $80^{\prime} \mathrm{s}$, research focused on seemingly unrelated $T$. cruzi molecules evolved in parallel in Rio de Janeiro, Buenos Aires and San Francisco before they converged. In 1983, Mendonça-Previato and co-workers characterized GP25, a glycoprotein with mucin-like properties $(40 \% \mathrm{w} / \mathrm{w}$ carbohydrate) isolated from boiled extracts of epimastigotes [46]. Immunological studies soon revealed that GP25 was highly antigenic in the context of infection, because chronic chagasic patients usually presented high-titers of anti-GP25 IgG antibodies in the serum $[47,48]$. Subsequent studies showed that GP25 was a proteolytic fragment arising from the cleavage of biosynthetic precursors of higher molecular mass (GP57/51) [49]. In 1989, Cazzulo and co-workers characterized the major lysosomal cysteine proteinase of epimastigotes as a cathepsin L-like enzyme, which they originally 
designated as "cruzipain" [50]. Shortly afterwards, the Nterminal sequence of GP57/51, combined to evidence from enzymatic studies, indicated that GP57/51 and cruzipain were either identical or closely related molecular entities $[51,52]$, both of which localized to the flagellar pocket of the parasites. In a parallel study, Eakin, McKerrow, and coworkers [53] described the partial DNA sequence of a cathepsin L-like gene of T. cruzi. Additional DNA sequencing performed in Buenos Aires [54] revealed the presence of a 130 amino acids long carboxy-terminal extension (CTE/GP25) linked to the catalytic (central) domain through a post-translationally modified polythreonine hinge [55] that is sensitive to autocatalytic cleavage $[49,56]$. In a major step forward, Eakin and co-workers [57] described the full-length sequence and organization of the cruzipain gene and expressed the enzymatically active form of the protease, truncated at the CTE. Synthesized as a single polypeptide chain, the pre-pro-enzyme undergoes maturation by proteolytic excision of the N-terminal pro domain, a feature shared by all papain-like enzymes [57]. Focusing their attention on the single N-linked glycan (Asn-255) of CTE, Parodi, Cazzulo and co-workers demonstrated presence of high mannose hybrid mono-antennary as well as complex bi-antennary oligosaccharide chains [58].

The access to the full-length sequence of cruzipain had immediate impact in immunology research. In 1993, Arnholdt et al. [59] assayed human cruzipain-specific $\mathrm{CD}^{+} \mathrm{T}_{\mathrm{H}} 1$ cell lines with overlapping synthetic peptides spanning the cruzipain sequence. Although limited to a few chagasic patients, their data indicated that some human $\mathrm{T}$ cell epitopes were mapped to the catalytic domain of cruzipain [59]. A1though the biochemical heterogeneity of the oligosaccharide chains of CTE/GP25 [58,60], and the polymorphism in the multicopy cruzipain gene family [61] posed difficulties for the characterization of epitopes recognized by patients' antibodies, Duschak have recently advanced the proposition that sulfate moiety present in the high-mannose type of oligosaccharide chain of the CTE [60] might be critical for antibody binding [45].

\section{Cruzipain, a Chemotherapeutic Target of $T$. cruzi}

In 1992, Meirelles and co-workers [62] demonstrated that intracellular parasite growth in primary cultures of cardiomyocytes was arrested upon addition of Z-(SBz)CysPhe- $\mathrm{CHN}_{2}$, a membrane-permeable irreversible inhibitor designed against cathepsin L. By treating heavily parasitized cardiomyocytes with a related radiolabeled probe, Z-Phe$\mathrm{Tyr}^{125}-\mathrm{CHN}_{2}$, the Brazilian team showed that it bound irreversibly to cruzipain [62]. Independent studies confirmed these observations [63,64], providing the rationale for development of novel therapeutic drugs. In 1995, McGrath and co-workers [65] solved the X-ray structure of cruzipain complexed with irreversible inhibitors, starting the era of molecular medicine in Chagas disease. Among the novel inhibitors synthesized at UCSF [66], Engel, Boyle and coworkers focused on K11777, a vinylsulfone derivative devoid of toxicity [67]. This drug completely eradicated $T$. cruzi from immunodeficient mice [68] and prevented heart damage in dogs [69]. Altogether, these studies provided proof of concept that cruzipain/cruzain inhibitors can be used as therapeutic drugs, at least so in the preclinical settings.
In a recent review, Caffrey and Steverding proposed a new terminology for kinetoplastid $\mathrm{C} 1$ peptidases [70]. Accordingly, the cathepsin L-like cruzain/cruzipain should be termed TcrCATL. Whichever the nomeclature to be adopted, it must take into account the fact that some cruzipain isoforms are not reasily categorized as proposed. For example, Lima and co-workers reported that recombinant cruzipain 2, an isoform encoded by a more divergent gene (88\% identity) [71,72], displays a narrower substrate preference as compared to cruzipain 1 (TcrCATL). We ascribed the difference in substrate specificity of cruzipain 2 to presence of a few non-conserved substitutions in the $\mathrm{S} 2$ subsite, and to a minor extent, to substitutions found in the $S_{1}$ ' and the $S_{2}$ ' sites [73]. Of note, Mu-F-hF-VSPh, a potent inhibitor of recombinant cruzain (i.e., cruzipain 1), also inactivates recombinant cruzipain 2, albeit at reduced efficiency (Lima, APL and Scharfstein, J, unpublished data). Although cruzipain 2 is expressed in mammalian infective stages [72], its functional role remains unknown. In addition to the closely related cruzipain 1 and 2 isoforms, the CL Brenner genome data [74,75] show 3 additional members of the clan A of C1-family: a single copy gene encoding cathepsin B, which was only partially characterized [76,77], and two putative enzymes, respectively annotated as cathep$\sin \mathrm{S}$ and bromelain-like protein.

\section{Cysteine Proteases Drive Parasite Penetration in Non- Phagocytic Host Cells}

In 1985, Piras and co-workers reported that T. cruzi invasion of fibroblasts involved the participation of proteases [78]. Exploring the role of cruzipain (GP57/51) in these effects, Meirelles and co-workers [62] reported several years later that irreversible inhibitors designed for cathepsin $\mathrm{L}$ reduced the parasite ability to invade primary cardiomyocytes. Clues to understand the mechanisms of action of $T$. cruzi proteases emerged from studies conducted by Andrews, Burleigh and co-workers [79,80]. While examining TCTs extracts, these authors found that oligopeptidase B was able to generate a soluble factor that induces elevation in the intracellular free $\mathrm{Ca}^{+}$concentration $\left(\left[\mathrm{Ca}^{2+}\right]_{i}\right)$ of mammalian cells. Transduced by pertussis toxin-sensitive seventransmembrane G-protein coupled receptors (GPCRs), the signal(s) generated by oligopeptidase B stimulated parasite entry via the $\mathrm{Ca}^{+2} /$ lysosomal pathway [81-83]. A few years later, studies performed with endothelial cells and cardiomyocytes showed that TCTs generated kinin peptides, which then enhanced parasite invasion through the signaled two alternative GPCR subtypes, $\mathrm{BK}_{2} \mathrm{R}$ or $\mathrm{BK}_{1} \mathrm{R}[84,85]$. Studies with synthetic and natural cruzipain inhibitors suggested that cruzipain molecules diffusing into the secluded sites formed by the juxtaposition of host/parasite plasma membranes might process cell-bound kininogens, releasing kinins within such synaptic sites [84].

Originally described by Ming and co-workers [86], the involvement of the TGF-B-dependent signaling pathway in parasite infectivity was recently revitalized [87] by the findings that TGF- $\beta$ blockers reduce mortality and cardiac damage in acutely infected mice in [88]. Although host proteases are able to activate latent (inactive) forms of TGF- $\beta$ under physiological conditions, Whanabi and co-workers [87] suggested that $T$. cruzi is also able to generate the active form of 
this cytokine via as yet uncharacterized leupeptin-sensitive T. cruzi protease(s) [87]. Although speculative, it is conceivable that parasite proteases confined to synaptic clefts might activate latent TGF- $\beta$, as suggested for kinin generation. The multiplicity of proteolytic pathways that might drive host cell invasion by TCTs was further highlighted by the work of Santana and co-workers [89] appointing an in vitro role for POP Tc80 [89], an $80 \mathrm{kDa}$ prolyloligopeptidase that hydrolyzes human collagens type I/IV.

\section{Strain-Dependent Variability of Infective Phenotype Correlated with Cruzipain Activity}

Using a human myofibroblast cell line that does not express $\mathrm{BK}_{2} \mathrm{R}$ [82] Aparicio and co-workers [90] demonstrated that strain-dependent differences of parasite infectivity in vitro is causally linked to enzyme activity levels of cruzipain. After showing that TCTs-G (poorly infective) secreted low levels of active cruzipain enzyme as compared to TCTsDm28c, these authors rescued the infective phenotype of GTCTs by adding Dm28c TCT conditioned medium to the cultures. Importantly, the enhancement induced by Dm28 conditioned medium was abolished by the broad spectrum inhibitor E-64, thus implying that the enhancement was dependent on Dm28 cysteine protease activity. Of note, host cells pretreated with thapsigargin cancelled the effects of Dm28 conditioned medium, implying that signaling pathway involved mobilization of intracellular $\mathrm{Ca}^{2+}$ stores. At least two functionally distinct cruzipain isoforms (Lima, AP, unpublished data) were detected in the Dm28c conditioned medium, but the lack of isoform-specific inhibitors has precluded an assessment of their individual roles in proteasemediated enhancement of $\mathrm{G}$ strain infectivity. Intriguingly, these authors pointed out that infection-promoting activity of Dm28c conditioned medium depends on an as yet unidentified membrane-bound factor [90]. It is still unclear whether cruzipain can liberate invasion-promoting factors from GPIlinked mucins [91] an/or from members of the GP85/TSfamily of antigens [92,93] displayed on shed lipid vesicles [94]. Noteworthy in this context, Magdesian and co-workers $[95,96]$ recently demonstrated that synthetic versions of the FLY-containing peptide sequence of Tc85 (highly conserved in the Gp85/TS family) stimulates parasite entry in epithelial cells via mechanisms that involve (i) dephosphorylation of intermediate filaments, such as cytokeratin 18, and (ii) ERK1/2-dependent rearrangements of actin skeleton [96]. Future studies may determine if upon diffusion from flagellar pocket, lysosomal-like cysteine proteinases such as cruzipain I and/or cruzipain II may digest TS molecules that are either shed [94] and/or bound to host cell surfaces [25,97]. Once released, the FLY-containing peptide may be either fit to stimulate parasite uptake by host cells, or may execute this function after undergoing trimming by host/parasite peptidases.

\section{Molecular Interplay Between Cruzipain and its Endo- genous Inhibitor, Chagasin, Influences the Infective Phenotype of $T$. cruzi}

Tomas and Kelly were the first to report that the expression of the multicopy cruzipain genes is controlled posttranscriptionally [98]. In 2001, the characterization of chagasin as tight-binding endogenous cysteine protease inhibitor by Monteiro and co-workers [99] yielded clues to understand how the parasite regulates the enzymatic function of cruzipain in vivo [100]. Encoded by a single-gene, chagasin is a 110 amino acid-long single chain protein whose developmental expression is inversely correlated with cruzipain expression levels [99]. Recently classified in the MEROPS database as family 142 , belonging to clan IX, chagasin is the prototype of a new family of cysteine protease inhibitors expressed in other protozoa and even in bacteria [101]. In agreement with earlier in silico predictions [102], the NMR structure of the protein in solution [103], followed by the Xdiffraction data of crystals made of chagasin either bound to falcipain [104] or complexed to papain [105] revealed the presence of an immunoglobulin-like domain scaffold projecting loops that interact with the active site of target cysteine proteases. Similar features were described for a chagasin orthologue of L. mexicana, operationally designated as inhibitor of cysteine peptidases (ICP) [106].

Studies performed with biotinylated cysteine protease inhibitor or using specific antibodies demonstrated that cruzain/cruzipain transits the Golgi-endosomal pathway before being localized to pre-lysosomes/lysosomes in the posterior end of epimastigotes [107]. As reviewed elsewhere [108], the ratio between the expression levels of chagasin and cruzipain molecules changes throughout $T$. cruzi development. Consistent with the stringent metabolic requirements of replicating forms, cruzipain levels are high in epimastigotes, while chagasin is reciprocally expressed at low levels [99]. In TCTs, however, the ratio of cruzipain/chagasin is markedly decreased, suggesting that lysosomal proteolysis is more tightly regulated in these (metabolic quiescent) infective forms [99,100].

Functional studies were performed using Dm28 parasites engineered to express 4-fold more chagasin than wild type. The results from this study showed that chagasin overexpression impairs biological functions that are typically linked to cruzipain activity, such as ability to invade myofibroblasts in culture systems [100]. Reminiscent of the results already described with the weakly infective G-strain TCTs [90], the addition of conditioned medium derived from wild type Dm28c TCTs increased the infectivity of chagasin overexpressors [100]. Of note, the effect of Dm28 conditioned medium was blocked by irreversible cruzipain inhibitors, further suggesting that the deficient infective phenotype of chagasin overexpressors was due to impaired processing/secretion of active cysteine proteases [100].

Santos and co-workers [100] showed that chagasin colocalized with cruzipain both in the Golgi complex and reservosomes of epimastigotes. In both organelles, the protein inhibitor was found as part of tight-binding molecular complexes with cruzipain [100]. Biochemical analysis suggested that chagasin inhibits the autocatalytic removal of the prosegment from pro-cruzipain zymogen(s), thereby exerting control a limiting step of cruzipain maturation in epimastigotes [100]. The titration of chagasin and of cruzipain levels in several $T$. cruzi strains revealed that the inhibitor/enzyme molar ratio in epimastigotes is kept fairly constant $(\sim 1: 50)$ despite strain-dependent variability in the expression of the individual proteins [100]. Of note, however, G strain parasites display drastically reduced cysteine protease activity, although the expression of chagasin remains normal. The 
mechanism underlying this deficiency in active cruzipain remains to be clarified. Mature forms of cruzipain 2 are able to process pro-cruzipain I [100], suggesting that the transactivation process originally described for L. mexicana cysteine proteases [109] may also occur in T. cruzi. It will be interesting to know if the poorly infective $T$. cruzi G-strains has deficient ability to trans-activate pro-cruzipain, perhaps reflecting reduced expression and/or production of unstable cruzipain isoforms. Whichever the explanation, these studies suggested that the strain-dependent changes in infective phenotype may reflect deficient cruzipain maturation at early stage of trafficking and/or dampening of active enzyme by chagasin.

\section{TCTs Exploit the Kinin-Releasing Activity of Cruzipain to Invade Host Cells Via the GPCR/Ca ${ }^{2+} /$ lysosomal Pathway}

The term "kinin" refers to a small group of nona/decapeptides proteolytically excised from an internal portion of high or low molecular weight kininogens (HK/LK) by the action of specialized proteases, collectively referred as "kininogenases" [110]. Once released, the shortlived kinins (half life of $<15 \mathrm{sec}$ in the plasma) exert their biological effects by the paracrine mode, through the activation of distinct sub-types of heterotrimeric GPCRs, $\mathrm{BK}_{2} \mathrm{R}$ (constitutively expressed) and $\mathrm{BK}_{1} \mathrm{R}$ (induced in injured/inflamed tissues) [111]. While intact kinins (BK or $\mathrm{LBK}$ ) are the agonists for $\mathrm{BK}_{2} \mathrm{R}$, the ligand for the inducible $\mathrm{BK}_{1} \mathrm{R}$ is [des-Arg]-bradykinin or [des-Arg]-lysyl-BK, i.e., the truncated peptides generated by the removal of the $C$ terminal Arginine from the BK/LBK by carboxypeptidase $\mathrm{N} / \mathrm{M}$, i.e., kininase I. Long-range effects on $\mathrm{BK}_{2} \mathrm{R}$ localized at the vascular lining are prevented by the metabolic action of kinin-degrading peptidases, such as the angiotensin converting enzyme (ACE) [112].

In the physiological settings, plasma kallikrein releases the nonapeptide bradykinin $(\mathrm{BK})$ from $\mathrm{HK}$, whereas tissue kallikrein liberates lysyl-BK from HK/LK [110]. Bacterial pathogens, such as Porphyromonas gingivalis, the gramnegative bacteria that causes gingival inflammation and periodontitis, can directly activate the kinin system through the activity of gingipains, a class of cysteine protease that is insensitive to inhibition by the cystatin-like domains of kininogens [113,114]. Although the kinin peptides have been traditionally viewed as classical mediators of acute inflammation (e.g., inducers of edema formation, vasodilation and pain sensations), we have recently demonstrated that bradykinin is an endogenous danger signal that steers $T_{H} 1$ polarization through the activation of conventional CD11c ${ }^{+}$DCs [115]. Consistent with these findings, studies in mice infected by $P$. gingivalis [114] or by $T$. cruzi [116-119] demonstrated that kinins released in extravascular infections sites act as a bridge between inflammation, innate immunity and adaptive (T-cell dependent) immunity development. Another recent precedent that kinins stimulate $\mathrm{T}$ cell dependent acquired immunity came from studies in mice infected with Listeria [120].

In the late 90's, Del Nery, Juliano and co-workers observed that cruzipain could efficiently hydrolyze synthetic peptides that corresponded to the flanking side bonds of lysyl-bradykinin, an internal decapeptide of kininogens [121].
Encouraged by these biochemical observations, these workers demonstrated that cruzipain could release kinins, albeit slowly, from soluble forms of purified kininogens [121]. Initially, the concept that cruzipain could acts as a kininreleasing enzyme ("kininogenase") seemed paradoxical because kininogens display a cystatin-like domain overlapping with a cell-attachment site, i.e., soluble kininogens function as tight-binding active site inhibitors of papain-like proteases, such as cruzipain [122]. However, kinetic studies indicated that $\mathrm{HK}$ degradation by cruzipain was facilitated by cooperative interactions of heparan sulfate proteoglycans with both the HK substrate and the parasite protease [123]. We then examined if TCTs (Dm28 strain) could activate the kinin system in the biological settings. Using host cell invasion as a read-out, we demonstrated that living TCTs (Dm28c) rely on the kinin-releasing activity of cruzipain to infect cells that naturally overexpress BKRs, such as human umbilical vein endothelial cells (HUVECs) and cardiomyocytes [84-85]. Assays performed with transfected CHO-BKR cells and HUVECs confirmed that TCTs stimulated the $\left[\mathrm{Ca}^{2+}\right]_{\mathrm{i}}$ 'lysosomal pathway of host cell invasion through cruzipain-dependent signaling of $\mathrm{BK}_{2} \mathrm{R}$ or $\mathrm{BK}_{1} \mathrm{Rs}[84,85]$. Noteworthy, ACE, a kinin-degrading metallopeptidase naturally overexpressed by cardiovascular cells, reduced the parasite ability to invade HUVECs or cardiomyocytes via the constitutively expressed $\mathrm{BK}_{2} \mathrm{R}$ pathway [84,85,112]. However, the host protective effects of ACE were not manifested if the parasites were cultivated with TLR4-activated HUVECs [85]. Under these conditions, the TCTs can invade the activated HUVECs via the inducible $\mathrm{BK}_{1} \mathrm{R}$ pathway, irrespective of ACE [85]. Of note, inhibitors of carboxypeptidase $\mathrm{M} / \mathrm{N}$ (kininase I) blocked the $\mathrm{BK}_{1} \mathrm{R}$-dependent pathway of host cell invasion, suggesting that the primary kinin agonist released from cell-bound kininogens (by cruzipain) is rapidly converted into the truncated $\mathrm{BK}_{1} \mathrm{R}$ ligand, [des-Arg]kinins by carboxypeptidase N/M (kininase I) [85]. In conclusion, these studies suggested that $\mathrm{BK}_{1} \mathrm{R}$ upregulation by host cells exposed to parasite proinflammatory molecules and/or to endogenous inflammatory signals might offer a window of opportunity for parasite invasion via signaling of the ubiquitous $\mathrm{BK}_{1} \mathrm{R}$ pathway [85].

\section{Kinins Released by Cruzipain Link Inflammation to Type-1 Immunity}

Strategically positioned in peripheral tissues and in secondary lymphoid organs, the sentinel cells of the innate immune system sense the presence of pathogens through different types of pattern-recognition receptors. While much emphasis has been placed on the studies of the vascular functions of kinins, their innate effector roles remain virtually unknown. A few years ago, we reported that exogenous BK potently induces dendritic cell (DC) maturation, driving IL12-dependent $\mathrm{T}_{\mathrm{H}} 1$ responses through the activation of $\mathrm{BK}_{2} \mathrm{R}$ [115]. While these studies were in progress, we initiated studies in mice models of infection to evaluate if kinins could act as a bridge between inflammation and innate/adaptive immunity. To this end, we infected mice with pathogens that are empowered with kinin-releasing cysteine proteases, e.g., $T$. cruzi and $P$. gingivalis $[114,116-$ 118]. Although the bulk of information about host resistance to acute $T$. cruzi infection was generated in systemically infected (i.p. route) mice $[39,117]$, it is technically difficult 
to study the dynamics of early-phase inflammation under these experimental conditions. Monteiro and co-workers [116] overcame this limitation by injecting the kininreleasing pathogen in tissues that permit assessement of edematogenic inflammation. In the case of periodontal infection by the gram-negative anaerobic bacteria $P$. gingivalis, the pathogen was injected intramucosally (mandibular vestibule) [114] while in the case of T. cruzi the flagellated protozoa was injected in the mouse paw $[116,118]$. In order to potentiate kinin system activation in mice subcutaneously infected with $T$. cruzi, the naïve mice were pre-treated with a single-dose of ACE inhibitor (captopril). As already explained, the ACE blocker increases the half-life of kinins liberated in the infected paw tissues, and these effects translate into increased BKR-dependent edema [85,116]. Importantly, TCTs failed to evoke edema responses in $\mathrm{BK}_{2} \mathrm{R}$-deficient mice, or in animals pre-treated with the $\mathrm{BK}_{2} \mathrm{R}$ antagonist $\mathrm{HOE}-140$, irrespective of the captopril administration [116]. Notably, TCTs pretreated with Z11777 (cruzipain inhibitor) were uncapable of evoking $\mathrm{BK}_{2} \mathrm{R}$-dependent edema in mice pretreated with $\mathrm{ACE}$ inhibitors [116]. These results indicated that TCTs induce edematogenic inflammation in cruzipain $>\mathrm{BK}_{2} \mathrm{R}$-dependent manner while ACE, countermodulates these effects [85,116,118].

At first sight it seemed surprising that mice injected with epimastigotes did not develop significant edema in animals pretreated with ACE inhibitors [85,116] because these insect-stage parasites were known to secrete high-levels of cruzipain. Pertinently, mice injected with purified (activated) cruzipain also failed to develop appreciable edema, thus indicating that cruzipain enzyme activity (in TCTs) was necessary but not sufficient to induce edema via the kinin $/ \mathrm{BK}_{2} \mathrm{R}$ pathway. The explanation for the discrepant phenotypes of TCTs and epimastigotes emerged as purified tGPI and cruzipain were injected alone, or combined, in the mouse paw [116]. These experiments showed that tGPI (TLR2 ligand) combined to cruzipain developed potent edematogenic inflammation in captopril-treated wild type mice but failed to evoke these responses in mice pretreated with $\mathrm{HOE}-140$, in $\mathrm{BK}_{2} \mathrm{R}^{-/-}$or in $\mathrm{TLR}^{-/-}$mice. Consistent with these results, TCTs failed to evoke significant paw edema in captopril-treated TLR2 ${ }^{-/-}$mice, or in neutrophildepleted animals [116,118]. Collectively, these results suggested that parasite-induced activation of TLR2 $\rightarrow$ neutrophils is a pre-requisite for activation of the kinin system via the cruzipain $\rightarrow$ kinin $/ \mathrm{BK}_{2} \mathrm{R}$-dependent pathway. Using intravascular microscopy in the hamster cheek pouch, Monteiro and co-workers [116] studied the early-phase microvascular responses elicited by topically applied TCTs. In contrast to epimastigotes, which failed to induce plasma leakage through post-capillary venules, these workers observed that leukocytes adhere to the endothelium shortly before the onset of plasma leakage. Schmitz and coworkers [118] turned to the mouse model to characterize the role of CXC chemokines in the TLR2-dependent inflammation (paw edema) ignited by TCTs. Their results indicated that TCTs initiate inflammation by inducing TLR2dependent secretion of CXC chemokines in tissue resident macrophages [118]. Acting on proximal microvascular beds, KC/MIP-2 activates CXCR2 expressed by neutro- phils/endothelium. A discrete leakage of plasma occurs, allowing for the accumulation of plasma-borne proteins, including kininogens, in the peripheral sites of infection. Further downstream, TCTs rely on cruzipain to degrade kininogens bound to heparan sulfate proteoglycans, releasing the short-lived kinins in extravascular sites of infection. As the concentrations of kinins rises, the interstitial edema is further increased as result of activation of endothelium BKRs [85, 116,118]. Tightly regulated by ACE, the interstitial edema controlled by $\mathrm{BK}_{2} \mathrm{R}$ amplifies the early-phase of inflammation ignited by the activation of TLR $2 \rightarrow$ CXCR 2 /neutrophils [116,118].

After dissecting the role of TLR2/CXCR2/BK ${ }_{2} \mathrm{R}$ in the dynamics of inflammation elicited by TCTs, we then examined if immature DCs residing in interstitial tissues could sense the proteolytically released kinin "danger" signals via $\mathrm{BK}_{2} \mathrm{R}$. This question was initially addressed by isolating CD11 $\mathrm{c}^{+}$DCs rom the draining lymph nodes of wild type infected mice pretreated with ACE inhibitor. In line with our working hypothesis, Monteiro and co-workers [116] found that the frequency of IL-12-producing DCs were sharply increased in kinin/ $\mathrm{B}_{2} \mathrm{R}$-dependent manner. Prompted by these findings, Monteiro and co-workers [116] then asked if $\mathrm{kinin} / \mathrm{B}_{2} \mathrm{R}$-dependent induction of IL-12-producing CD11 $\mathrm{c}^{+}$DCs was linked to upregulated adaptive (type-1) immune responses. The analysis of cytokine profile of Agspecific $\mathrm{T}$ cells isolated from draining lymph nodes confirmed that $\mathrm{BK}_{2} \mathrm{R}$ was critically involved in the induction of $\mathrm{T}_{\mathrm{H}} 1$ responses in wild-type mice pretreated with captopril. Interestingly, injection of epimastigotes (which, as mentioned, fails to activate the kinin system because they lack potent TLR2 ligands) did not stimulate type-1 immunity via the $\mathrm{BK}_{2} \mathrm{R}$ pathway, despite $\mathrm{ACE}$ inhibitor administration [116]. As predicted, T. cruzi injection in neutrophil-depleted mice, in TLR2-deficient mice or in $\mathrm{B}_{2} \mathrm{R}$-deficient mice did not lead to development of type-1 effector $\mathrm{T}$ cells. Importantly, the deficient type-1 immune responses observed in TLR2-deficient mice and neutrophil-depleted mice was rescued by injecting TCTs along with exogenous kininogen (HK). Controls showed that HK-dependent reconstitution of type-1 responses in the TLR2/neutrohil-deficient mice was nullified in mice pretreated with HOE-140 [116]. Furthermore, mice injected with purified HK combined to TCTs pre-treated with cruzipain inhibitors also failed to restore type-1 responses via the $\operatorname{kinin} / \mathrm{BK}_{2} \mathrm{R}$ pathway. Collectively, the experiments performed in the s.c. model of $T$. cruzi infection demonstrated that endogenously released kinins, rather than TLR2 ligands of TCTs, are the downstream effector innate signals that guide $T_{H} 1$ development [116]. The evidence that the $T L R 2 / \mathrm{BK}_{2} \mathrm{R}$ axis provides a bridge between inflammation to adaptive immunity was recently confirmed in a mouse gingivitis model induced by the gram-negative bacterium $P$. gingivalis [114]. Armed with potent kinin-releasing cysteine proteases (gingipains), this periodontopathogen spontaneously induce type- 1 immune responses via the TLR2 $\rightarrow$ neutrophil/ $\mathrm{BK}_{2} \mathrm{R}$ pathway, i.e., there was no need to artificially interfere with kinin homeostasis through the administration of ACE inhibitors, as done in the s.c. model of T. cruzi infection [116].

Summarizing the informational content of this section, the data obtained in the subcutaneous model of $T$. cruzi 
infection support the notion that activation of the kinin system in extravascular sites of infection increases the intensity of inflammation ignited via the TLR2/CXCR2/ neutrophil pathway. Although the raise of kinin "danger" signals may lead to the maturation of conventional CD $11 \mathrm{c}^{+}$ DCs, the efficiency of this process is tigthly controlled by the kinin-degrading activity of ACE.

\section{Activation by Kinins are Critically Required for Generation of Immunoprotective $\mathrm{CD4}^{+}$and $\mathrm{CD8}^{+} \mathrm{T}$ Cells}

Although the footpad infection model allowed us to dissect the activation pathways underlying TCT-evoked inflammation, the animals were resistant to acute infection, thus precluding analysis of the role of the TLR2/CXCR2/ $\mathrm{B}_{2} \mathrm{KR}$ axis in host resistance. We therefore addressed this issue by turning to the more traditional i.p. infection model [117]. As illustrated in Fig. (1), we predicted that plasma proteins would diffuse freely to secondary lymphoid tissues (such as the spleen) of acutely infected mice. According to our working hypothesis, (i) extracellular T. cruzi would have direct access to blood-borne kininogens (ii) kinins would be released (via cruzipain) in the proximity of conventional
CD11 $\mathrm{c}^{+}$DCs residing in the spleen parenchyma [117]. Strikingly, $\mathrm{B}_{2}$ KR-deficient (B6) mice succumbed, while wild type infected mice resisted, as expected [117]. Analysis of the parasite tissue burden in the heart revealed that it was significantly increased in $\mathrm{BK}_{2} \mathrm{R}^{-/-}$mice. Notably, the heigthened susceptibility of cardiac $\mathrm{B}_{2} \mathrm{KR}^{-/-}$tissues was paralleled by a signficant drop in the frequencies of intracardiac antigen-specific IFN- $\mathrm{\gamma}$-producing $\mathrm{T}$ cells in $\mathrm{B}_{2} \mathrm{KR}^{-/-}$mice. Surprisingly, we found similar frequencies of antigen-specific effector $\mathrm{CD}^{+} \mathrm{T}$ cells and $\mathrm{CD} 4^{+} \mathrm{T}$ cells in the spleen of wild-type and $\mathrm{BK}_{2} \mathrm{R}$-deficient mice, suggesting that the lymphoid compartment of the mutant strain was well preserved at early stages the infection [117]. However, as the acute infection progressed, there was a sharp decline in the frequency of type- 1 effector cells in $\mathrm{B}_{2} \mathrm{KR}^{--\mathrm{-}}$ mice, both in lymphoid and cardiac tissues (more accentuated) [117]. Notably, the decayed $\mathrm{T}_{\mathrm{H}} 1$ response of $\mathrm{B}_{2} \mathrm{KR}$-deficient mice was accompanied by a rise in the pro-inflammatory $T_{H} 17$ subset [117], implying that $\mathrm{B}_{2} \mathrm{KR}$ signaling prevents induction and/or expansion of $\mathrm{T}_{\mathrm{H}} 17$ type cells in acutely infected mice. Importantly, the hypothesis that $\mathrm{DC}$ signaling via $\mathrm{B}_{2} \mathrm{KR}$ is critically required for induction of protective effector $\mathrm{T}$ cells

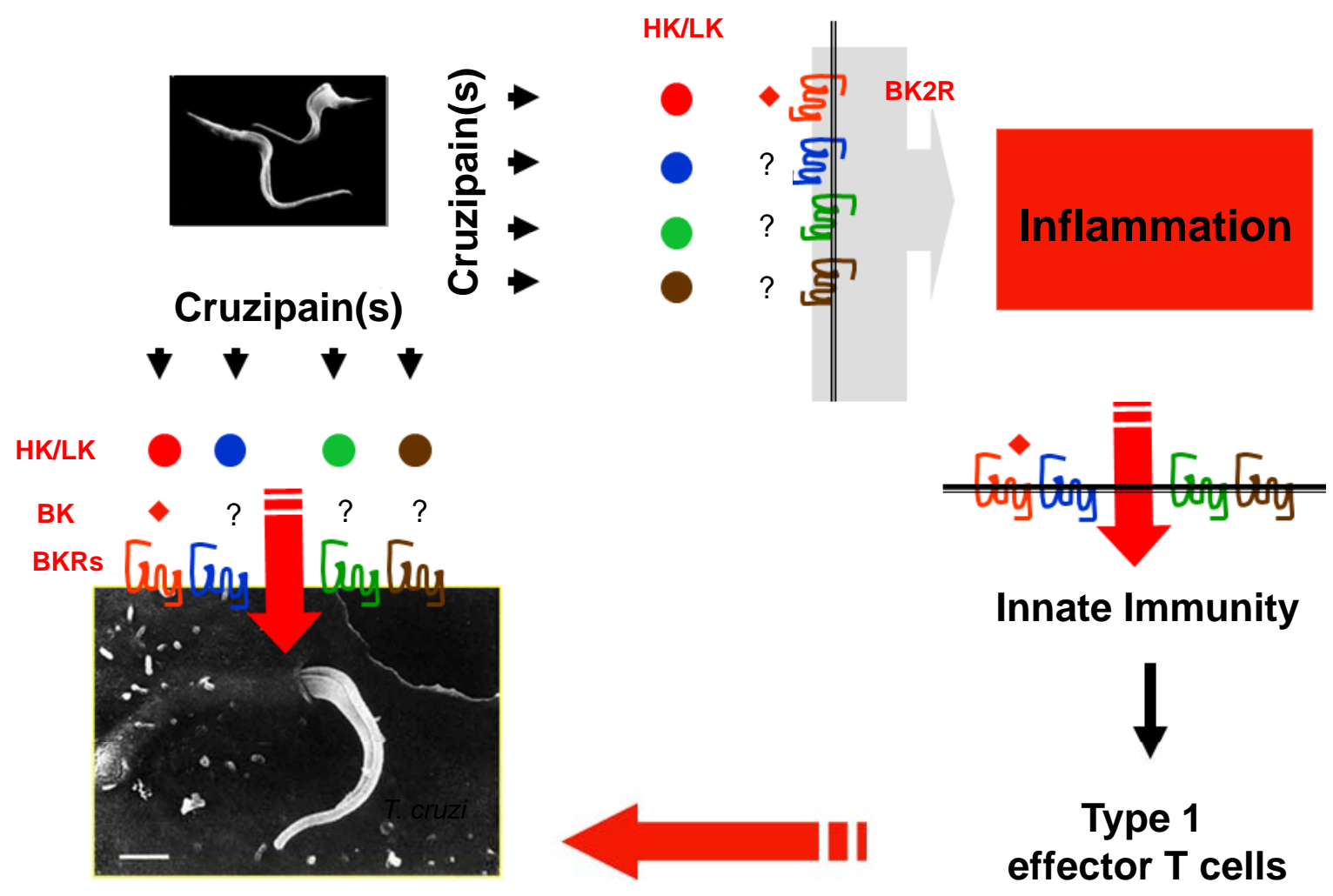

Fig. (1). General scheme illustrating how cruzipain activity may translate into mutual benefits to the host-parasite balance. At the left side of the panel, TCTs rely on cruzipain to excise GPCR agonists (colored circles) from various precursor molecules (host and/or parasite origin). Once released, some of these GPCR agonists (e.g., bradykinin) potentiate parasite invasion of host cells by triggering the GPCR/Ca2+ -lysosomal pathway via BKRs [ref], while other peptides may induce pathogen internalization via a distinct pathway. The dual role of cruzipain is illustrated at the right side of the panel. Some of the peptide ligands that stimulate parasite entry in host cells (for example, bradykinin) may amplify inflammation through the signaling of GPCRs expressed in the endothelium and/or innate sentinel cells (eg. DCs). The intensity of type 1 responses steered by the cruzipain $>$ kinin/BK2R pathway is fine-tuned by the kinin-degrading metalopeptidases, such as ACE [112]. The original prints showing parasite penetration of host cells were prepared by Dr. Norma Andrews, University of Maryland. 


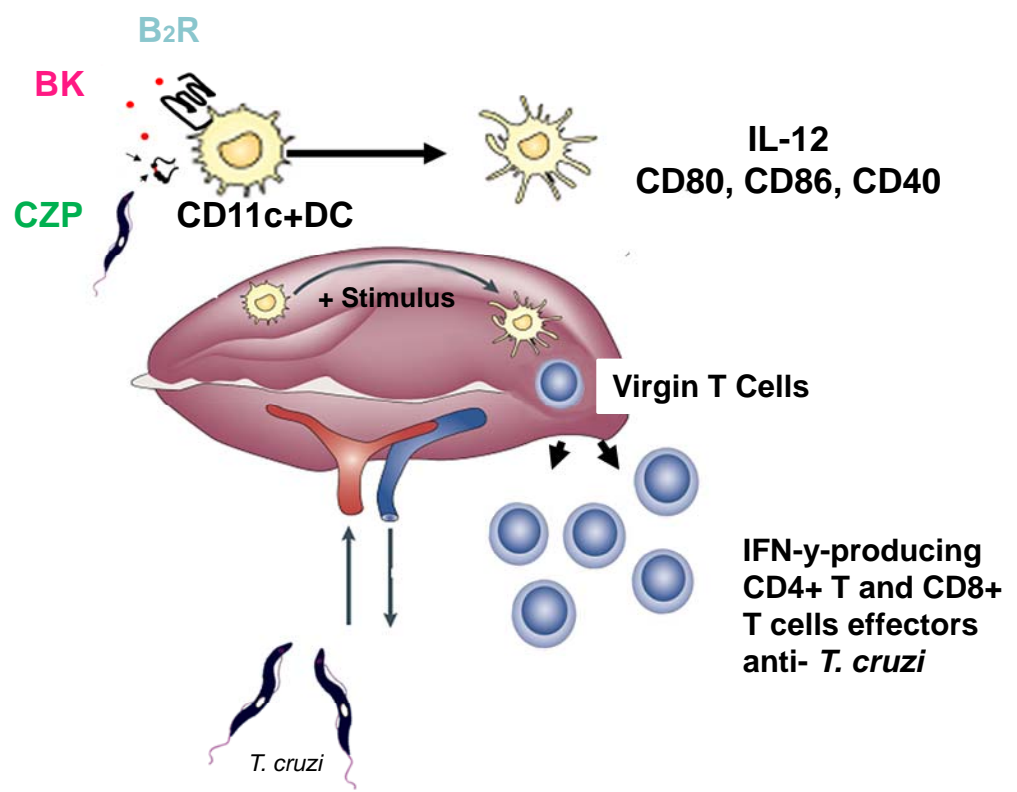

Fig. (2). Kinins proteolytically released by $T$. cruzi trypomastigotes induce immunoprotective $T$ cells via activation of $B K_{2} R$ of CD11 $^{+}$DCs. Unlike the situation in peripheral sites of infection [116,118], in the traditional intraperitoneal model of acute infection the plasma proteins (including kininogen molecules) diffuse freely through the spleen. The scheme depicts the immunostimulatory role of cruzipain as the TCTs (Dm28 strain) reach the splenic stroma [117]. Top, TCTs release kinins from cell-bound kininogens via cruzipain. Once released, the short-lived kinins act as endogenous danger signals, i.e., they activate B2KR expressed by splenic CD11 ${ }^{+}$DCs, thereby converting these APCs into type-1 inducers (through upregulation of CD80.CD86, CD40 and IL12). It is proposed that these antigen-loaded IL12 producing DCs migrate to $\mathrm{T}$ cell rich areas of secondary lymphoid tissues (spleen), where they activate naïve $\mathrm{T}$ cells and/or memory $\mathrm{T}$ cells, thus generating immunoprotective (type-1) T cells that migrate to peripheral tissues, such as the heart [117].

was corroborated by adoptive cell transfer of wild type DCs into $\mathrm{B}_{2} \mathrm{KR}^{-/-}$deficient mice. This procedure not only rescued the resistant phenotype in the recipient $\mathrm{B}_{2} \mathrm{KR}^{-/-}$mice but also restored the development of protective IFN- $\gamma$-producing $\mathrm{CD} 4^{+} \mathrm{CD} 44^{+}$and $\mathrm{CD} 8^{+} \mathrm{CD} 44^{+}$effector $\mathrm{T}$ cells in the recipient mutant mice, while conversely dampening the potentially detrimental $\mathrm{T}_{\mathrm{H}} 17\left(\mathrm{CD}^{+}\right.$subset) responses [117]. Adding weight to these observations, the analysis of $\mathrm{CD} 11 \mathrm{c}^{+} \mathrm{DC}$ interaction with TCTs showed that IL-12 and co-stimulatory molecules (CD86, CD80, CD40) were strongly upregulated in wild type DCs, but not in $\mathrm{B}_{2} \mathrm{KR}^{-/-}$DCs. Moreover, parasites pre-treated with irreversible inhibitors of cruzipain failed to induce overt maturation of wild-type DCs, in keeping with the proposition that cruzipain enzymatically generates the $\mathrm{B}_{2} \mathrm{KR}$ agonist [117]. Future studies may determine if fluctuations in the levels of kinins in the myocardium of chronic chagasic patients may modulate the function of interstitial DCs. Of note, independent studies indicate that monocyte-derived human DCs express BKRs, but unlike the conventional CD $11 \mathrm{c}^{+}$DCs isolated from the mouse spleen, these in vitro generated human APCs failed to undergo maturation upon stimulation with kinins [124]. Given the marked phenotypic heterogeneity of DCs [125] it remains to be determined if other human DC subtypes are responsive to kinins in the context of natural infection/inflammation.

\section{Cruzipain May have Duals Functions in Chronic Heart Pathology}

Early immunohistochemical studies revealed presence of cruzipain deposits in the myocardium of CCM patients
[126]. Unlike their $\mathrm{pH}$ sensitive mammalian counterparts (cathepsin $\mathrm{B} / \mathrm{L}$ ), the lysosomal-like cysteine protease of $T$. cruzi is relatively stable in physiological $\mathrm{pH}$. Depending on the availability of plasma proteins in the extravascular spaces, cruzipain may activate the kinin system. Low levels of kinins may stimulate nitric oxide via signaling of $\mathrm{BK}_{2} \mathrm{R}$ expressed by the endothelium lining, perhaps exerting beneficial effects to the chagasic heart. On the other hand, highlevels of kinins may evoke interstitial edema and aggravate inflammation and chronic immunopathology through the triggering of inducible $\mathrm{BK}_{1} \mathrm{R}$ subtype [85]. Another example of the multifaceted roles of cruzipain came from a recent study showing that cruzipain is capable of differentially cleaving three chemokines: CCL-2, CCL-12 and CCL-13 [127]. Analysis of the proteolyzed products showed that CCL-2 preserved its chemotactic activity, while the closely related CCL-12 and CCL-13 chemokines lost their agonist activity upon enzymatic treatment. Surprisingly, however, these authors found that a synthetic 14-mer cruzipainderived chemokine peptide displayed antagonistic function in assays of in vitro migration of monocytic cells and calcium flux release [127]. If confirmed by assays performed with living parasites, this mechanism may illustrate how cruzipain-mediated proteolysis may facilitate parasite adaptation in the inflamed/hostile tissue environment.

Whichever the origin of the natural substrates of cruzipain, it is likely that its extravascular functions may be shortlived. First, it is possible that cruzipain may undergo spontaneous inactivation due to oxidation of active-site cysteine 
residue. Second, the active protease may be entrapped by $\alpha_{2}-$ macroglobulin, and/or form tight-binding tri-molecular complexes by binding to one or two molecules of soluble kininogens [128], as soon as these plasma proteins diffuse into peripheral sites of infection. Interestingly, the localization of cruzipain antigen overlapped with those of infiltrating macrophage-like cells expressing the $\alpha_{2}$-macroglobulin scavenger receptor $\left(\alpha_{2} \mathrm{MR} / \mathrm{CD} 91\right)$ [126]. Interestingly in this context, Morrot and co-workers [126] showed that $\alpha_{2}$-Mcruzipain complexes were rapidly internalized by human monocytes via the $\alpha_{2} \mathrm{MR} / \mathrm{CD} 91$ scavenger receptor [126]. Notably, the activation threshold of class II MHC-restricted $\mathrm{CD}^{+} \mathrm{T}$ cells from chronic chagasic patients was significantly reduced as result of efficient processing and presentation of cruzipain-derived peptides by these APCs [126]. In another study, Araujo-Jorge and co-workers [129] reported that $T$. cruzi-infected mice deficient in $\alpha_{2}$-macroglobulin genes developed an exacerbated myocarditis. Of further interest, levels of serum antibodies against $T$. cruzi were substantially decreased in the $\alpha_{2} \mathrm{M}^{--}$mice [129]. These results suggest that the $\alpha_{2}$-macroglobulin, acting via $\alpha_{2}$ MR/CD91 enhaces $T$ cell responses against cruzipain epi-

\section{SOPMSMARY AND PERSPECTIVES}

After three decades of research, the knowledge emerging from studies of cruzipain structure and function(s) suggests that the enzymatic versatility of this lysosomal cysteine protease is highly beneficial for host-parasite equilibrium. Apart from its intracellular role, TCTs exploit cruzipain to generate multiple infection-promoting signals through the cleavage of host and endogenous substrates (Fig. 1). Although some $T$. cruzi strains may rely on the kinin-releasing activity of cruzipain to opportunistically invade cardiovascular cells via the $B_{1} K R$ pathway in the inflamed myocardium, recent studies in mice systemically infected by $T$. cruzi have linked the extravascular activation of the kinin system to the development of protective immunity. As illustrated in Fig. (2), kinins released by TCTs induce generation/expansion of immunoprotective $\mathrm{T}$ cells via mechanisms involving activation of CD $11 \mathrm{c}^{+}$DCs via the $\mathrm{B}_{2} \mathrm{KR} / \mathrm{IL}-12$ pathway. Studies of the dynamics of inflammation elicited by TCTs (subcutaneous model) revealed that extent of activation of the kinin cascade in peripheral tissues depends on the molecular interplay of several factors, namely: (i) tGPI-mucin/cruzipain (ii) the TLR2/CXCR2/ ${ }_{2} \mathrm{KR}$ axis and (iii) kinin-degrading enzymes, such as ACE. Future studies may clarify if dysfunctions in the regulation of cruzipain activity in extravascular sites of infection may influence pathogen outcome in the settings of human Chagas disease.

\section{ACKNOWLEDGEMENTS}

Our research work on $T$. cruzi is currently supported by funds from CNPq, FAPERJ (PRONEX) and grants from Instituto Nacional de Ciência e Tecnologia em Biologia Estrutural e BioImagem (INBEB).

\section{REFERENCES}

[1] Reis DD, Jones EM, Tostes S, Gazzinelli G, Colley DG, McCurley T. Characterization of inflammatory infiltrates in chonic chagasic myocardial lesions: presence of TNF-alpha+ cells and dominance of Granzyme A+, CD8+ lymphocytes. Am J Trop Med Hyg 1993; 43: 637-44.
Jones EM, Colley DG, Tostes S, Lopes ER, Vnencak-Jones CL, McCurley TL. Amplification of a Trypanosoma cruzi DNA sequence from inflammatory lesions in human chagasic cardiomyopathy. Am J Trop Med Hyg 1993; 48(3): 348-57.

[3] Higuchi MD, Ries MM, Aiello VD, et al. Association of an increase in $\mathrm{CD}^{+} \mathrm{T}$ cells with the presence of Trypanosoma cruzi antigens in chronic, human, chagasic myocarditis. Am J Trop Med Hyg 1997; 56(5): 485-89.

[4] Palomino SA, Aiello VD, Higuchi ML. Systematic mapping of hearts from chronic chagasic patients: the association between the occurrence of histopathological lesions and Trypanosoma cruzi antigens. Ann Trop Med Parasitol 2000; 94(6): 571-79.

[5] Tarleton R. Parasite persistence in the etiology of Chagas disease. Int J Parasitol 2004; 31: 550-54.

[6] Leon JS, Engman DM. The significance of autoimmunity in the pathogenesis of Chagas heart disease. Front Biosci 2003; 8: e31522.

[7] Ribeiro-Dos-Santos R, Mengel JO, Postol E, et al. A heart-specific $\mathrm{CD} 4+\mathrm{T}$-cell line obtained from a chronic chagasic mouse induces carditis in heart-immunized mice and rejection of normal heart transplants in the absence of Trypanosoma cruzi. Parasite Immunol 2001; 23(2): 93-101.

[8] Scharfstein J, Morrot A. A role for extracellular amastigotes in the immunopathology of Chagas disease. Mem Inst Oswaldo Cruz 1999; 94(1): 51-63.

[9] Freire-de-Lima CG, Nascimento DO, Soares MB, et al. Uptake of apoptotic cells drives the growth of pathogenic trypanosome in macrophages. Nature 2000; 403(6766): 194-203.

[10] Laucella SA, Postan M, Martin D, et al. Frequency of interferongamma -producing $\mathrm{T}$ cells specific for Trypanosoma cruzi inversely correlates with disease severity in chronic human Chagas disease. J Infect Dis 2004; 189(5): 909-18.

[11] Bustamante JM, Bixby LM, Tarleton RL. Drug-induced cure drives conversion to a stable and protective $\mathrm{CD}^{+} \mathrm{T}$ central memory response in chronic Chagas disease. Nat Med 2008; 14(5): 542-50.

[12] Macedo AM, Pena SD. Genetic variability of Trypanosoma cruzi: implications for the pathogenesis of chagas disease. Parasitol Today $1998 ; 14(3): 119-24$.

[13] Fonseca SG, Moins-Teisserenc H, Clave E, et al. Identification of multiple HLA-A*0201-restricted cruzipain and FL-160 CD8+ epitopes recognized by $\mathrm{T}$ cells from chronically Trypanosoma cruziinfected patients. Microbes Infect 2005; 7(4): 688-97.

[14] Gomes JA, Bahia-Oliveira LM, Rocha MO, Martins-Filho OA, Gazzinelli G, Correa-Oliveira R. Evidence that development of severe cardiomyopathy in human Chagas disease is due to a Th1specific immune response. Infect Immun 2003; 71(3): 1185-93.

[15] Costa GC, da Costa Rocha MO, Moreira PR, et al. Functional IL10 gene polymorphism is associated with Chagas disease cardiomyopathy. J Infect Dis 2009; 199(3): 451-4.

[16] Rossi MA. Microvascular changes as a cause of chronic cardiomyopathy in Chagas' disease. Am Heart J 1990; 10: 233-36.

[17] Morris SA, Tanowitz H, Wittner M, Bilezikian JP. Pathophysiological insights into the cardiomyopathy of Chagas' disease. Circulation 1990; 82: 1900-10.

[18] Tanowitz HB, Burns ER, Sinha AK, et al. Enhanced platelet adherence and aggregation in Chagas' disease: a potential pathogenic mechanism for cardiomyopathy. Am J Trop Med Hyg 1990; 43(3): 274-81.

[19] Higuchi ML, Fukasawa S, De Brito T, Parzianello LC, Bellotti G, Ramires JÁ. Different microcirculatory and interstitial matrix patterns in idiopathic dilated cardiomyopathy and Chagas' disease: a three dimensional confocal microscopy study. Heart 1999; 82(3): 279-85.

[20] Tanowitz HB, Huang H, Jelicks LA, et al. Role of endothelin 1 in the pathogenesis of chronic chagasic heart disease. Infect Immun 2005; 73(4): 2496-503.

[21] Hassan GS, Mukherjee S, Nagajyothi F, et al. Trypanosoma cruzi infection induces proliferation of vascular smooth muscle cells. Infect Immun 2006; 74(1): 152-9.

[22] Libby P, Alroy J, Pereira ME. A neuraminidase from Trypanosoma cruzi removes sialic acid from the surface of mammalian myocardial and endothelial cells. J Clin Invest 1986; 77(1): 127-35.

[23] Previato JO, Andrade AF, Pessolani MC, Mendonça-Previato L. Incorporation of sialic acid into Trypanosoma cruzi macromolecules. A proposal for a new metabolic route. Mol Biochem Parasitol 1985 ; 16(1): 85-96. 
[24] Schenkman S, Jiang MS, Hart GW, Nussenzweig V. A novel cell surface trans-sialidase of Trypanosoma cruzi generates a stagespecific epitope required for invasion of mammalian cells. Cell 1991; 65(7): 1117-25.

[25] Todeschini AR, Girard MF, Wieruszeski JM, et al. Trans-Sialidase from Trypanosoma cruzi binds host T-lymphocytes in a lectin manner. J Biol Chem 2002; 277(48): 45962-68.

[26] Dias WB, Fajardo FD, Graça-Souza AV, et al. Endothelial cell signalling induced by trans-sialidase from Trypanosoma cruzi. Cell Microbiol 2008; 10(1): 88-99.

[27] Affranchino JL, Ibañez CF, Luquetti AO, et al. Identification of a Trypanosoma cruzi antigen that is shed during the acute phase of Chagas' disease. Mol Biochem Parasitol 1989; 34(3): 221-8.

[28] Andrade ZA, Andrade SG, Correa R, Sadigursky M, Ferrans VJ. Myocardial changes in acute Trypanosoma cruzi infection. Ultrastructural evidence of immune damage and the role of microangiopathy. Am J Pathol 1994; 144(6): 1403-11.

[29] Duthie MS, Cetron MS, Van Voorhis WC, Kahn SJ. Trypanosoma cruzi-infected individuals demonstrate varied antibody responses to a panel of trans-sialidase proteins encoded by SA85-1 genes. Acta Trop 2005; 3(3): 317-29.

[30] Ashton AW, Mukherjee S, Nagajyothi FN, et al. Thromboxane A2 is a key regulator of pathogenesis during Trypanosoma cruzi infection. J Exp Med 2007; 204(4): 929-40.

[31] Gomes MT, Monteiro RQ, Grillo LA, et al. Platelet-activating factor-like activity isolated from Trypanosoma cruzi. Int J Parasitol 2006; 36(2): 165-73.

[32] Ropert C, Gazzinelli RT. Innate recognition, cell signaling and proinflammatory responses during infection with Trypanosoma cruzi. In: Denkers EY, Gazzinelli RT, Eds. Protozoans in macrophages (Texas), Austin: Landes Biosciences 2007; pp. 49-66.

[33] Campos MA, Almeida IC, Takeuchi O, et al. Activation of Tolllike receptor-2 by glycosylphosphatidylinositol anchors from a protozoan parasite. J Immunol 2001; 167: 416-23.

[34] Oliveira AC, Peixoto JR, Arruda LB, et al. Expression of functional TLR4 confers proinflammatory responsiveness to Trypanosoma cruzi glycoinositolphospholipids and higher resistance to infection with $T$. cruzi. J Immunol 2004; 173: 5688-96.

[35] Ouaissi A, Guilvard E, Delneste Y, et al. The Trypanosoma cruzi Tc52-released protein induces human dendritic cell maturation, signals via Toll-like receptor 2 , and confers protection against lethal infection. J Immunol 2002; 168: 6366-74.

[36] Bafica A, Santiago HC, Goldszmid R, Ropert C, Gazzinelli RT, Sher A. Cutting edge: TLR9 and TLR2 signaling together account for MyD88-dependent control of parasitemia in Trypanosoma cruzi infection. J Immunol 2006; 177: 3515-19.

[37] Almeida IC, Gazzinelli RT. Proinflammatory activity of glycosylphosphatidylinositol anchors derived from Trypanosoma cruzi: structural and functional analyses. J Leukoc Biol 2001; 70: 467-77.

[38] Serrano AA, Schenkman S, Yoshida N, Mehlert A, Richardson JM, Ferguson MA. The lipid structure of the glycosylphosphatidylinositol-anchored mucin-like sialic acid acceptors of Trypanosoma cruzi changes during parasite differentiation from epimastigotes to infective metacyclic trypomastigote forms. J Biol Chem 1995; 270(45): 27244-53.

[39] Tarleton RL. Immune system recognition of Trypanosoma cruzi. Curr Opin Immunol 2007; 19: 430-34.

[40] Peterson CA, Krumholz A, Burleigh BA. Toll-like receptor 2 regulates Interleukin-IB-dependent cardiomyocytes hypertrophy triggered by Trypanosoma cruzi. Infection Immunity 2005; 73(10): 6974-80.

[41] Coelho PS, Klein A, Talvani A, et al. Glycosylphosphatidylinositol-anchored mucin-like glycoproteins isolated from Trypanosoma cruzi trypomastigotes induce in vivo leukocyte recruitment dependent on MCP-1 production by IFN- $\gamma$-primed-macrophages. J Leukocyte Biol 2002; 71: 837-44.

[42] Cazzulo JJ, Stoka V, Turk V. Cruzipain, the major cysteine proteinase from the protozoan Trypanosoma cruzi. Bio Chem 1997; 378(1): 1-10.

[43] McKerrow JH. Development of cysteine protease inhibitors as chemotherapy for parasitic diseases: insight on safety, target validation and mechanism of action. Int J Parasitol 1999; 29(6): 83337.

[44] Bryant C, Kerr ID, Debnath M, et al. Novel non-peptidic vinylsulfones targeting the S2 and S3 subsites of parasite cysteine proteases. Bioorg Med Chem Lett 2009; 19(21): 6218-21.
[45] Duschak VG, Couto AS. Cruzipain,the major cysteine protease of Trypanosoma cruzi: a sulfated glycoprotein antigen as relevant candidate for vaccine development and drug target. A review. Curr Med Chem 2009; 16: 3174-202.

[46] Mendonça-Previato L, Gorin PA, Braga AF, Scharfstein J, Previato JO. Chemical structure and antigenic aspects of complexes obtained from epimastigotes of Trypanosoma cruzi. Biochemistry 1983; 22(21): 4980-87.

[47] Scharfstein J, Rodrigues MM, Alves CA, et al. Trypanosoma cruzi: description of a highly purified surface antigen defined by human antibodies. J Immunol 1983; 131(2): 972-76.

[48] Scharfstein J, Luquetti A, Murta AC, et al. Chagas' disease: serodiagnosis with purified Gp25 antigen. Am J Trop Med Hyg 1985; 34(6): 1153-60.

[49] Scharfstein J, Schechter M, Senna M, et al. Trypanosoma cruzi: characterization and isolation of a $57 / 51,000 \mathrm{~m} . \mathrm{w}$. surface glycoprotein (GP57/51) expressed by epimastigotes and bloodstream trypomastigotes. J Immunol 1986; 137(4): 1336-41.

[50] Cazzulo JJ, Cazzulo Franke MC, Martinez J, et al. Some kinetic properties of a cysteine proteinase (cruzipain) from Trypanosoma cruzi. Biochim Biophys Acta 1990; 1037(2): 186-91.

[51] Murta AC, Persechini PM, Padron Td, et al. Structural and functional identification of GP57/51 antigen of Trypanosoma cruzi as a cysteine proteinase. Mol Biochem Parasitol 1990; 43(1): 27-38.

[52] Cazzulo JJ, Couso R, Raimondi A, et al. Further characterization and partial amino acid sequence of a cysteine proteinase from Trypanosoma cruzi. Mol Biochem Parasitol 1989; 33(1): 33-41.

[53] Eakin AE, Bouvier J, Sakanari JA, Craik CS, McKerrow JH. Amplification and sequencing of genomic DNA fragments encoding cysteine proteases from protozoan parasites. Mol Biochem Parasitol 1990; 39(1): 1-8.

[54] Aslund L, Henriksson J, Campetella O, et al. The C-terminal extension of the major cysteine proteinase (cruzipain) from Trypanosoma cruzi. Mol Biochem Parasitol 1991; 45(2): 345-47.

[55] Cazzulo JJ, Martínez J, Parodi AJ, Wernstedt C, Hellman U. On the post-translational modifications at the $\mathrm{C}$-terminal domain of the major cysteine proteinase (cruzipain) from Trypanosoma cruzi. FEMS Microbiol Lett 1992; 79(1-3): 411-16.

[56] Hellman U, Wernstedt C, Cazzulo JJ. Self-proteolysis of the cysteine proteinase, cruzipain, from Trypanosoma cruzi gives a major fragment corresponding to its carboxy-terminal domain. Mol Biochem Parasitol 1991; 44(1): 15-21.

[57] Eakin AE, Mills AA, Harth G, et al. The sequence, organization, and expression of the major cysteine protease (cruzain) from Trypanosoma cruzi. J Biol Chem 1992; 267(11): 7411-720.

[58] Parodi AJ, Labriola C, Cazzulo JJ. The presence of complex-type oligosaccharides at the C-terminal domain glycosylation site of some molecules of cruzipain. Mol Biochem Parasitol 1995; 69(2): 247-55.

[59] Arnholdt AC, Piuvezam MR, Russo DM, et al. Analysis and partial epitope mapping of human $\mathrm{T}$ cell responses to Trypanosoma cruzi cysteinyl proteinase. J Immunol 1993; 151(6): 3171-79.

[60] Barboza M, Duschak VG, Fukuyama Y, et al. Structural analysis of the N-glycans of the major cysteine proteinase of Trypanosoma cruzi. Identification of sulfated high-mannose type oligosaccharides. FEBS J 2005; 272(15): 3803-15.

[61] Campetella O, Henriksson J, Aslund L, Frasch AC, Pettersson U, Cazzulo JJ. The major cysteine proteinase (cruzipain) from Trypanosoma cruzi is encoded by multiple polymorphic tandemly organized genes located on different chromosomes. Mol Biochem Parasitol 1992; 50(2): 225-34.

[62] Meirelles MN, Juliano L, Carmona E, et al. Inhibitors of the major cysteinyl proteinase (GP57/51) impair host cell invasion and arrest the intracellular development of Trypanosoma cruzi in vitro. Mol Biochem Parasitol 1992; 52(2): 175-84.

[63] Harth G, Andrews N, Mills AA, Engel JC, Smith R, McKerrow JH. Peptide-fluoromethyl ketones arrest intracellular replication and intercellular transmission of Trypanosoma cruzi. Mol Biochem Parasitol 1993; 58(1): 17-24.

[64] Franke de Cazzulo BM, Martínez J, North MJ, Coombs GH, Cazzulo JJ. Effects of proteinase inhibitors on the growth and differentiation of Trypanosoma cruzi. FEMS Microbiol Lett 1994; 124(1): 81-6.

[65] McGrath ME, Eakin AE, Engel JC, et al. The crystal structure of cruzain: a therapeutic target for Chagas' disease. J Mol Biol 1995; 247(2): 251-9. 
[66] Roush WR, Cheng J, Knapp-Reed B, et al. Potent second generation vinyl sulfonamide inhibitors of the trypanosomal cysteine protease cruzain. Bioorg Med Chem Lett 2001; 11(20): 2759-62.

[67] Engel JC, Doyle PS, Hsieh I, et al. Cysteine protease inhibitors cure an experimental Trypanosoma cruzi infection. J Exp Med 1998; 188(4): 725-34.

[68] Doyle PS, Zhou YM, Engel JC, McKerrow JH. A cysteine protease inhibitor cures Chagas' disease in an immunodeficient-mouse model of infection. Antimicrob Agents Chemother 2007; 51(11): 3932-39.

[69] Barr SC, Warner KL, Kornreic BG, et al. A cysteine protease inhibitor protects dogs from cardiac damage during infection by Trypanosoma cruzi. Antimicrob Agents Chemother 2005; 49(12): 5160-61.

[70] Caffrey CR, Steverding D. Kinetoplastid papain-like cysteine peptidases. Mol Biochem Parasitol 2009; 167(1): 12-19.

[71] Lima AP, Tessier DC, Thomas DY, Scharfstein J, Storer AC, Vernet $\mathrm{T}$. Identification of new cysteine protease gene isoforms in Trypanosoma cruzi. Mol Biochem Parasitol 1994; 67(2): 333-38.

[72] Lima AP, dos Reis FC, Serveau C, et al. Cysteine protease isoforms from Trypanosoma cruzi, cruzipain 2 and cruzain, present different substrate preference and susceptibility to inhibitors. Mol Biochem Parasitol 2001; 114(1): 41-52.

[73] dos Reis FC, Júdice WA, Juliano MA, Juliano L, Scharfstein J, Lima AP. The substrate specificity of cruzipain 2, a cysteine protease isoform from Trypanosoma cruzi. FEMS Microbiol Lett 2006; 259(2): 215-20.

[74] El-Sayed NM, Myler PJ, Bartholomeu DC, et al. The genome sequence of Trypanosoma cruzi, etiologic agent of Chagas disease. Science 2005; 309(5733): 409-15.

[75] Kosec G, Alvarez V, Cazzulo JJ. Cysteine proteinases of Trypanosoma cruzi: from digestive enzymes to programmed cell death mediators. Biocell 2006; 30(3): 479-90.

[76] Nóbrega OT, Santos Silva MA, Teixeira AR, Santana JM. Cloning and sequencing of tccb, a gene encoding a Trypanosoma cruzi cathepsin B-like protease. Mol Biochem Parasitol 1998; 97(1-2): 235-40.

[77] Yong V, Schmitz V, Vannier-Santos MA, et al. Altered expression of cruzipain and a cathepsin B-like target in a Trypanosoma cruzi cell line displaying resistance to synthetic inhibitors of cysteineproteinases. Mol Biochem Parasitol 2000; 109(1): 47-59.

[78] Piras MM, Henriquez D, Piras R. The effect of proteolytic enzymes and protease inhibitors on the interaction Trypanosoma cruzifibroblasts. Mol Biochem Parasitol 1985; 14(2): 151-63.

[79] Burleigh BA, Caler EV, Webster P, et al. A cytosolic serine endopeptidase from Trypanosoma cruzi is required for the generation of $\mathrm{Ca}^{2+}$ signaling in mammalian cells. J Cell Biol 1997; 136(3): 609-20.

[80] Burleigh BA, Woolsey AM. Cell signalling and Trypanosoma cruzi invasion. Cell Microbiol 2002; 4(11): 701-11.

[81] Tardieux I, Webster P, Ravesloot J, et al. Lysosome recruitment and fusion are early events required for trypanosome invasion of mammalian cells. Cell 1992; 71(7): 1117-30.

[82] Andrews NW. Regulated secretion of conventional lysosomes. Trends Cell Biol 2000; 10: 316-21.

[83] Leite MF, Moyer MS, Andrews NW. Expression of the mammalian calcium signaling response to Trypanosoma cruzi in Xenopus laevis oocytes. Mol Biochem Parasitol 1998; 92(1): 1-13.

[84] Scharfstein J, Schmitz V, Morandi V, et al. Host cell invasion by Trypanosoma cruzi is potentiated by activation of bradykinin $\mathrm{B}(2)$ receptors. J Exp Med 2000; 192(9): 1289-300.

[85] Todorov AG, Andrade D, Pesquero JB, et al. Trypanosoma cruzi induces edematogenic responses in mice and invades cardiomyocytes and endothelial cells in vitro by activating distinct kinin receptor (B1/B2) subtypes. FASEB J 2003; 17: 73-5.

[86] Ming M, Ewen ME, Pereira ME. Trypanosome invasion of mammalian cells requires activation of the TGF beta signaling pathway. Cell 1995; 82(2): 287-96.

[87] Waghabi MC, Keramidas M, Feige JJ, Araujo-Jorge TC, Bailly S. Activation of transforming growth factor beta by Trypanosoma cruzi. Cell Microbiol 2005; 7(4): 511-7.

[88] Waghabi MC, de Souza EM, de Oliveira GM, et al. Pharmacological inhibition of transforming growth factor beta signaling decreases infection and prevents heart damage in acute Chagas' disease. Antimicrob Agents Chemother 2009; 53(11): 4694-701.
[89] Bastos IM, Grellier P, Martins NF, et al. Molecular, functional and structural properties of the prolyl oligopeptidase of Trypanosoma cruzi (POP Tc80), which is required for parasite entry into mammalian cells. Biochem J 2005; 388(1): 29-38.

[90] Aparicio IM, Scharfstein J, Lima APCA. A new cruzipaindependent pathway of human cell invasion by Trypanosoma cruzi requiring trypomastigote membranes. Infect Immun 2004; 72: 5892-02

[91] Briones MR, Egima CM, Eichinger D, Schenkman S. Transsialidase genes expressed in mammalian forms of Trypanosoma cruzi evolved from ancestor genes expressed in insect forms of the parasite. J Mol Evol 1995; 41(2): 120-31.

[92] Freitas-Junior LH, Briones MR, Schenkman S. Two distinct groups of mucin-like genes are differentially expressed in the developmental stages of Trypanosoma cruzi. Mol Biochem Parasitol 1998; 93(1): 101-14.

[93] Alves MJ, Colli W. Role of the gp85/trans-sialidase superfamily of glycoproteins in the interaction of Trypanosoma cruzi with host structures. Subcell Biochem 2008; 47: 58-69

[94] Trocoli Torrecilhas AC, Tonelli RR, Pavanelli WR, et al. Trypanosoma cruzi: parasite shed vesicles increase heart parasitism and generate an intense inflammatory response. Microbes Infect 2009; 11(1): 29-39.

[95] Magdesian MH, Giordano R, Ulrich H, et al. Infection by Trypanosoma cruzi. Identification of a parasite ligand and its host cell receptor. J Biol Chem. 2001; 276(22): 19382-9.

[96] Magdesian MH, Tonelli RR, Fessel MR, et al. A conserved domain of the gp85/trans-sialidase family activates host cell extracellular signal-regulated kinase and facilitates Trypanosoma cruzi infection. Exp Cell Res 2007; 313(1): 210-8.

[97] Giordano R, Fouts DL, Tewari D, Colli W, Manning JE, Alves MJ. Cloning of a surface membrane glycoprotein specific for the infective form of Trypanosoma cruzi having adhesive properties to laminin. J Biol Chem 1999; 274(6): 3461-8.

[98] Tomas AM, Kelly JM. Stage-regulated expression of cruzipain, the major cysteine protease of Trypanosoma cruzi is independent of the level of RNA. Eur J Biochem 1996; 76(1-2): 91-103.

[99] Monteiro AC, Abrahamson M, Lima AP, Vannier-Santos MA, Scharfstein J. Identification, characterization and localization of chagasin, a tight-binding cysteine protease inhibitor in Trypanosoma cruzi. J Cell Sci 2001; 114(Pt 21): 3933-42.

[100] Santos CC, Santanna C, Terres A, et al. Chagasin, the endogenous cysteine-protease inhibitor of Trypanosoma cruzi, modulates parasite differentiation and invasion of mamalian cells. J Cell Sci 2005; 118: 901-15.

[101] Sanderson SJ, Westrop GD, Scharfstein J, et al. Functional conservation of a natural cysteine peptidase inhibitor in protozoan and bacterial pathogens. FEBS Lett 2003; 542: 12-6.

[102] Rigden DJ, Mosolov VV, Galperin MY. Sequence conservation in the chagasin family suggests a common trend in cysteine proteinase binding by unrelated protein inhibitors. Protein Sci 2002; 11: 97177.

[103] Salmon D, Aido-Machado R, Diehl A, et al. Solution structure and backbone dynamics of the Trypanosoma cruzi cysteine protease inhibitor chagasin. J Mol Biol 2006; 357: 1511-1521.

[104] Wang SX, Pandey KC, Scharfstein J, et al. The structure of chagasin in complex with a cysteine protease clarifies the binding mode and evolution of an inhibitor family. Structure 2007; 15(5): 535-43.

[105] Redzynia I, Ljunggren A, Bujacz A, Abrahamson M, Jaskolski M, Bujacz G. Crystal structure of the parasite inhibitor chagasin in complex with papain allows identification of structural requirements for broad reactivity and specificity determinants for target proteases. FEBS J 2009; 276(3): 793-806.

[106] Smith BO, Picken NC, Westrop GD, Bromek K, Mottram JC, Coombs GH. The structure of Leishmania mexicana ICP provides evidence for convergent evolution of cysteine peptidase inhibitors. J Biol Chem 2006; 281(9): 5821-8.

[107] Engel JC, Doyle PS, Palmer J, Hsieh I, Bainton DF, McKerrow JH. Cysteine protease inhibitors alter Golgi complex ultrastructure and function in Trypanosoma cruzi. J Cell Sci 1998; 11( Pt 5): 597-606.

[108] Scharfstein J, Lima AP. Roles of naturally occurring protease inhibitors in the modulation of host cell signaling and cellular invasion by Trypanosoma cruzi. Subcell Biochem 2008; 47: 140-54. 
[109] Brooks DR, Tetley L, Coombs GH, et al. Processing and trafficking of cysteine proteases in Leishmania mexicana. J Cell Sci 2000; 113: 4035-41

[110] Bhoola KD, Figueroa CD, Worthy K. Bioregulation of kinins: kallikreins, kininogens, and kininases. Pharmacol Rev 1992; 44: 180 .

[111] Blaukat A. Structure and signalling pathways of kinin receptors. Andrologia 2003; 35: 17-23.

[112] Scharfstein J, Monteiro AC, Schmitz V, Svensjö E. Angiotensinconverting enzyme limits inflammation elicited by Trypanosoma cruzi cysteine proteases: a peripheral mechanism regulating adaptive immunity via the innate kinin pathway. Biol Chem 2008; 389(8): 1015-24.

[113] Imamura T, Pike RN, Potempa J, Travis J. Pathogenesis of periodontitis: a major arginine-specific cysteine proteinase from Porphyromonas gingivalis induces vascular permeability enhancement through activation of the kallikrein/kinin pathway. J Clin Invest 1994; 94(1): 361-7.

[114] Monteiro AC, Scovino A, Raposo S, et al. Kinin danger signals proteolytically released by gingipain induce Fimbriae-specific IFNgamma- and IL-17-producing T cells in mice infected intramucosally with Porphyromonas gingivalis. J Immunol 2009; 183(6): 3700-11

[115] Aliberti J, Viola JP, Vieira-de-Abreu A, Bozza PT, Sher A, Scharfstein J. Cutting edge: bradykinin induces IL-12 production by dendritic cells: a danger signal that drives Th1 polarization. J Immunol 2003; 170(11): 5349-53

[116] Monteiro AC, Schmitz V, Svensjo E, et al. Cooperative activation of TLR2 and bradykinin B2 receptor is required for induction of type 1 immunity in a mouse model of subcutaneous infection by Trypanosoma cruzi. J Immunol 2006; 177(9): 6325-35

[117] Monteiro AC, Schmitz V, Morrot A, et al. Bradykinin B2 Receptors of dendritic cells, acting as sensors of kinins proteolytically released by Trypanosoma cruzi, are critical for the development of protective type-1 responses. PLoS Pathog 2007; 3(11): e185.

[118] Schmitz V, Svensjö E, Serra RR, Teixeira MM, Scharfstein J. Proteolytic generation of kinins in tissues infected by Trypanosoma cruzi depends on CXC chemokine secretion by macrophages activated via Toll-like 2 receptors. J Leukoc Biol 2009; 85(6): 100514.
[119] Scharfstein J, Schmitz V, Svensjö E, Granato A, Monteiro AC. Kininogens coordinate adaptive immunity through the proteolytic release of bradykinin, an endogenous danger signal driving dendritic cell maturation. Scand J Immunol 2007; 66(2-3): 128-36.

[120] Kaman WE, Wolterink AF, Bader M, Boele LC, van der Kleij D. The bradykinin B2 receptor in the early immune response against Listeria infection. Med Microbiol Immunol 2009; 198(1): 39-46.

[121] Del Nery E, Juliano MA, Lima AP, et al. Kininogenase activity by the major cysteinyl proteinase (cruzipain) from Trypanosoma cruzi. J Biol Chem 1997; 272: 25713-18

[122] Stoka V, Nycander M, Lenarcic B, et al. Inhibition of cruzipain, the major cysteine proteinase of the protozoan parasite, Trypanosoma cruzi, by proteinase inhibitors of the cystatin superfamily. FEBS Lett 1995; 370: 101-4.

[123] Lima AP, Almeida IL, Tersariol I, et al. Heparan sulfate modulates kinin release by Trypanosoma cruzi through the activity of cruzipain. J Biol Chem 2002; 2277: 5875-81.

[124] Bertram CM, Baltic S, Misso NL, et al. Expression of kinin B1 and B2 receptors in immature, monocyte-derived dendritic cells and bradykinin-mediated increase in intracellular $\mathrm{Ca}^{2+}$ and cell migration. J Leukoc Biol 2007; 81(6): 1445-54.

[125] Shortman K, Naik SH. Steady-state and inflammatory dendritic cell development. Nat Rev 2007; 7: 19-30.

[126] Morrot A, Strickland DK, Higuchi M de L, Reis M, Pedrosa R, Scharfstein J. Human T cell responses against the major cysteine proteinase (cruzipain) of Trypanosoma cruzi: role of the multifunctional $\alpha_{2}$-macroglobulin receptor in antigen presentation by monocytes. Internat Immunol 1997; 9(6): 825-834.

[127] Benítez-Hernández I, Méndez-Enríquez E, Ostoa P, et al. Proteolytic cleavage of chemokines by Trypanosoma cruzi's cruzipain inhibits chemokine functions by promoting the generation of antagonists. Immunobiol 2009; in press.

[128] Turk B, Stoka V, Turk V, Johansson G, Cazzulo JJ, Björk I. Highmolecular-weight kininogen binds two molecules of cysteine proteinases with different rate constants. FEBS Lett 1996; 391(1-2): 109-12.

[129] Waghabi MC, Coutinho CM, Soeiro MN, et al. Increased Trypanosoma cruzi invasion and heart fibrosis associated with high transforming growth factor beta levels in mice deficient in alpha(2)macroglobulin. Infect Immun 2002; 70(9): 5115-23.

(C) Julio Scharfstein; Licensee Bentham Open.

This is an open access article licensed under the terms of the Creative Commons Attribution Non-Commercial License (http://creativecommons.org/licenses/by-nc/3.0/) which permits unrestricted, non-commercial use, distribution and reproduction in any medium, provided the work is properly cited. 